\title{
Characterization of biopolymers and soy protein isolate-high-methoxyl pectin complex
}

\author{
Mírian Luisa Faria Freitas ${ }^{1 *}$, Kivia Mislaine Albano ${ }^{1}$ and Vânia Regina Nicoletti Telis ${ }^{1}$ \\ ${ }^{1}$ Laboratory of Physical Measures, Department of Food Engineering and Technology, Universidade \\ Estadual Paulista "Júlio de Mesquita Filho" - UNESP, São José do Rio Preto, SP, Brazil \\ *mirianlfreitas@yahoo.com.br
}

\begin{abstract}
This study aimed at characterizing the soy protein isolate and high-methoxyl pectin biopolymers individually, and the complexes formed by both at different proportions and $\mathrm{pHs}$ in order to find the most suitable $\mathrm{pH}$ and biopolymer ratios to food application as stabilizers. The biopolymers were evaluated through solubility, charges, turbidimetry, and optical microscopy analyses; the systems with the pair of biopolymers were analyzed through turbidimetry and optical microscopy. High-methoxyl pectin showed high solubility at all $\mathrm{pHs}$ investigated. The soy protein isolate showed low solubility at $\mathrm{pH} 4.5$, which is close to its isoelectric point, and complete solubility at $\mathrm{pH} 11.0$. The formation of complexes suggested an attractive interaction between the biopolymers, with high absorbance reading values and images of complexes from optical microscopy. These complexes were present in systems with pHs below the soy protein isolate's isoelectric point, with positive charges; the high-methoxyl pectin, however, had negative ones.
\end{abstract}

Keywords: attractive interaction, morphology, solubility, turbidimetry, zeta potential.

\section{Introduction}

Soy has been the most used material for industrial production of protein concentrates and isolates due to its high amount of proteins and its products' good technological performance. It also represents a vegetable alternative to lactic proteins ${ }^{[1]}$. The soy protein isolate (SPI) contains at least $90 \%$ protein; it is thus virtually free from lipids and carbohydrates $^{[2]}$.

Pectin, probably the most complex natural macromolecule, is the most common stabilizer used in protein-based acidic beverages, positively contributing to the final product's taste, stability, and texture, even if it is added in small amounts ${ }^{[3-5]}$. Although pectins are part of the majority of plant tissues, the number of commercial sources used is very limited ${ }^{[4]}$. The mainly polysaccharide used is derived from citric fruit and classified regarding the degree of esterification in: high-methoxyl pectins, when a half or more carboxyl groups are esterified, and low-methoxyl pectins, when less than a half the carboxyl groups are esterified ${ }^{[6]}$.

The formation of complexes between proteins and polysaccharides with opposite charges is a colloidal phenomenon involved in the structuring of several biological systems. There has been increasing interest in complexes formed by these biopolymers recently due to their potential applications in the food industry, being used as stabilizers in milk-based beverages, emulsifiers, foam stabilizers, fat replacers, besides being used in encapsulation, enzyme immobilization and recuperation, and protein separation processes, as explained by Dong et al. ${ }^{[7]}$ in revision of the literature.

Lam et al. ${ }^{[6]}$ carried out a study on pectin stability in protein acidic solutions, in which they used soy protein isolate. It was found that high-methoxyl pectin showed higher stability than low-methoxyl pectin. Jaramillo et al. ${ }^{[8]}$ observed that, at a $\mathrm{pH}$ near the isoelectric point of the SPI (around $\mathrm{pH} 4.0$ ), as pectin was added the protein solubility increased, which prevented its aggregation through an electrostatic interaction. They also verified that the resulting protein-polysaccharide complexes could bear thermal treatment, although a few changes in their properties occurred.

When the pair was used in emulsions, the polysaccharides increased the emulsion's physical stability through electrostatic and/or steric effects, because they modify the rheological properties of the interface and increase the viscosity of the emulsion $^{[9]}$.

Values of $\mathrm{pH}$ at which there are solubilization or biopolymer complexes formation do not depend or depend very little on the total concentration of the biopolymers. On the other hand, they are strongly related to the isoelectric point of the protein, the ratio between the biopolymers, their ionic strength and molar mass ${ }^{[10-12]}$.

Given this context, the aim of this study was to characterize the soy protein isolate and high-methoxyl pectin biopolymers through solubility, charges, turbidimetry, and optical microscopy analyses, besides characterizing the complex formed by the pair at different proportions and $\mathrm{pHs}$, evaluating turbidimetry and optical microscopy.

\section{Materials and Methods}

\subsection{Materials}

The biopolymers used were soy protein isolate (SPI) (Tovani Benzaquen Ingredientes ${ }^{\mathrm{TM}}$ ) and high-methoxyl pectin $(\mathrm{HM})\left(\mathrm{CP} \mathrm{Kelco}^{\mathrm{TM}}\right)$. For preparation of solutions, sodium azide was also used (Dinâmica ${ }^{\mathrm{TM}}$ ) and for $\mathrm{pH}$ 
adjustment, either $1 \mathrm{~N}$ hydrochloric acid (Dinâmica ${ }^{\mathrm{TM}}$ ) or sodium hydroxide (Dinâmica ${ }^{\mathrm{TM}}$ ) solutions were used.

\subsection{Methods}

Biopolymers were characterized, individually, through solubility, zeta potential, turbidimetry, and optical microscopy analyses at different pHs. The complex high-methoxyl pectin-soy protein isolate was characterized through turbidimetry analyses and optical microscopy at different proportions and $\mathrm{pHs}$.

\subsubsection{Solubility}

Biopolymers' solubility was determined, in triplicate, at pHs between 3.0 and $11.0( \pm 0.05)$, according to methodology proposed by Cano-Chauca et al. ${ }^{[13]}$ with some modifications. It was weighed $0.4 \mathrm{~g}$ of the biopolymer and completed up to $40 \mathrm{~mL}$ of solution with deionized water. The solutions were then moved to the shaker (Marconi, MA 830/A) for agitation for 3 hours and were left to hydrate during one night at room temperature. The next day, the desired $\mathrm{pH}$ was adjusted, the solutions were centrifuged at $3000 \times \mathrm{g}$ for 5 minutes (Hermle, Z $326 \mathrm{~K}$ ) and $20 \mathrm{~g}$ supernatant were transferred to previously dried Petri dishes. These were placed in a vacuum drying oven (Marconi, MA 030) at $60^{\circ} \mathrm{C}$ for $48 \mathrm{~h}$. Solubility was calculated by difference in weight.

\subsubsection{Preparation of stock solutions}

Stock solutions of the soy protein isolate were prepared by solubilizing the biopolymer in deionized water and adjusting its $\mathrm{pH}$ to $11.0( \pm 0.05)$, for a complete solubilization, according to the solubility result at that $\mathrm{pH}$ and as suggested by Jaramillo et al. ${ }^{[8]}$. Then they were stirred for $3 \mathrm{~h}$ in a magnetic stirrer and allowed to hydrate during one night for a complete hydration. The solutions had their desired pHs adjusted as the analyses were carried out.

Stock solutions of high-methoxyl pectin were prepared by solubilizing them in deionized water for $3 \mathrm{~h}$ in magnetic stirrer and hydration during one night at room temperature. The solutions had their desired pHs adjusted as the analyses were carried out.

It was added $0.04 \%$ sodium azide in stock solutions to avoid microorganisms growth.

\subsubsection{Zeta potential}

The charge analysis of soy protein isolate and high-methoxyl pectin biopolymers in $0.02 \%$ solution was carried out at $\mathrm{pHs}$ between 3.0 and $7.0( \pm 0.05)$. It was used a zeta potential analyzer (ZetaPALS), according to methodology proposed by Perrechil and Cunha ${ }^{[14]}$. Measurements were obtained in triplicate.

\subsubsection{Turbidimetry}

Solutions containing $0.05 \%$ soy protein isolate or high-methoxyl pectin were analyzed individually. Besides, different quantities from each biopolymer solutions were mixed in order to obtain systems with SPI:HM proportions of $1: 1,2: 1,3: 1$, and $4: 1$, with a final concentration of $0.05 \%$. Individual solutions and systems were analyzed at $\mathrm{pHs}$ between 3.0 and $7.0( \pm 0.05)$.
Turbidimetry analysis for each system was carried out according to methodology proposed by Antonov and Zubova $^{[15]}$, and Marfii ${ }^{[12]}$. After obtaining the desired $\mathrm{pH}$, it were measured the absorbance reading values of the aliquots in a spectrophotometer (Biospectro SP-220) at wavelength $590 \mathrm{~nm}$. According to the authors, the time between the adjustment of desired $\mathrm{pH}$ and absorbance reading in the spectrophotometer cannot be longer than $10 \mathrm{~s}$, because there may be precipitation of the formed complexes and interference in the readings after this time.

\subsubsection{Morphology}

The morphology of individual solutions and elaborated systems with SPI:HM proportions of 1:1, 2:1, 3:1, 4:1, with a biopolymer concentration of $0.05 \%$, was verified for $\mathrm{pHs}$ between 3.0 and $7.0( \pm 0.05)$ using an optical microscope (Olympus CX31) with 40x magnifying lenses coupled to a digital camera (Olympus SC30).

\section{Results and Discussion}

\subsection{Solubility}

As observed in Figure 1, high-methoxyl pectin is completely soluble, disregarding the $\mathrm{pH}$ of the solution. On the other hand, the soy protein isolate shows low solubility, around $10 \%$, at its isoelectric point (between $\mathrm{pH} 4.0$ and 5.0) and the solubility increases as it distances from this point, particularly in more alkaline conditions, reaching $100 \%$ at $\mathrm{pH} 11.0$.

Similar results were found by both Jaramillo et al. ${ }^{[8]}$, and Renkema et al. ${ }^{[16]}$ when studying the soy protein behavior at $\mathrm{pHs}$ from 3.0 to 7.0 , and 2.0 to 8.0 , respectively, confirming the $\mathrm{pH}$ between 4.0 and 5.0 as the isoelectric point of soy protein isolate, which is characterized by the lowest solubility due to charge neutralization.

According to Malhotra and Coupland ${ }^{[17]}$ and Jaramillo et al. ${ }^{[8]}$, the poor solubility of soy protein isolate around its isoelectric point can limit its application in acid foods. The soy protein isolate presents better functionality in conditions of

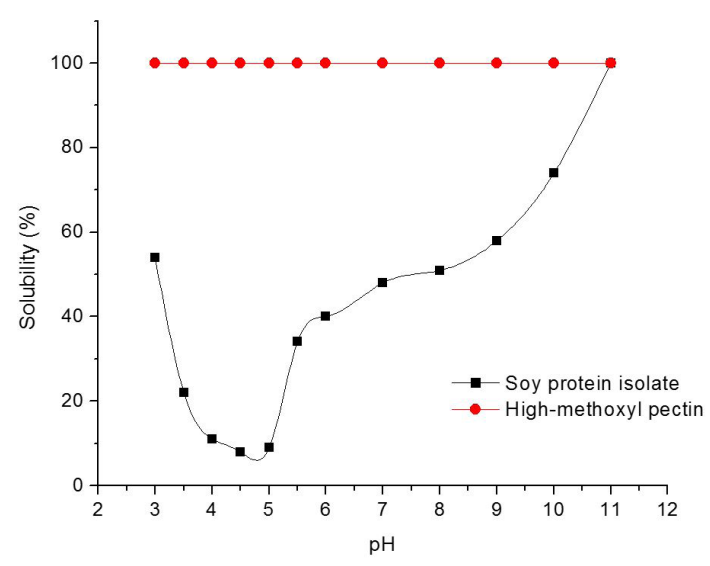

Figure 1. Solubility (\%) of soy protein isolate and high-methoxyl pectin vs $\mathrm{pH}$. 
higher solubility, since it can help emulsifying hydrophobic compounds as well as binding water in food systems.

Jaramillo et al. ${ }^{[8]}$ observed that the addition of pectin increased the solubility of soy protein isolate close to its isoelectric point and prevented the formation of very large aggregates. Moreover, thermal treatment $\left(30 \mathrm{~min}, 90{ }^{\circ} \mathrm{C}\right)$ enhanced the solubility of the soy protein isolate-pectin complexes close to the isoelectric point of protein.

Rocha et al. ${ }^{[18]}$ studied biodegradable composite films based on cassava starch and soy protein and verified that the increase in $\mathrm{pH}$ of the filmogenic solution favored solubility, possibly due to the distance of the soy protein isoelectric point, where the maximum solubility of the film was observed at $\mathrm{pHs}$ between 10 and 12 .

Therefore, soy protein isolate solutions used in the other analyses were prepared at $\mathrm{pH} 11.0$ and allowed to hydrate. Only after these steps they had their $\mathrm{pH}$ adjusted according to the necessity of the analysis.

\subsection{Zeta potential}

As reported by other authors, such as Harnsilawat et al. ${ }^{[19]}$, in the present study it was also observed that for polysaccharydes solutions such as high-methoxyl pectin when the $\mathrm{pH}$ increases, negative charges also increase, until this value reaches a plateau. To what proteins are concerned, below their isoelectric point, they acquire positive charges, whereas above this point, they acquire negative charges.

As observed in Figure 2, for the soy protein isolate, the charges close to zero were observed between $\mathrm{pHs} 4.0$ and 5.0, and the curve reaches zero at $\mathrm{pH}$ close to 4.6 , which confirms its isoelectric point.

Lam et al. ${ }^{[6]}$ and Jaramillo et al. ${ }^{[8]}$ reported similar results in their studies on charges of soy protein isolate; it was observed that the charges were zero at $\mathrm{pH} 4.5$ and 4.4, respectively.

It is possible to assume that at $\mathrm{pHs}$ below the protein's isoelectric point, the interaction between the protein and the pectin is attractive, once the pectin is negatively charged and the protein is positively charged ${ }^{[6]}$.

For the studied biopolymers, at $\mathrm{pH} 3.5$ it is possible that there is an attractive interaction and formation of complexes due to the fact that they have opposite charges and at quite high values.

\subsection{Turbidimetry}

The absorbance readings at different $\mathrm{pHs}$ for the biopolymer solutions and for the systems with different proportions of soy protein isolate:high-methoxyl pectin (SPI:HM) are shown in Figure 3.

As expected, the solution containing only high-methoxyl pectin presented a low and constant absorbance reading value for all studied $\mathrm{pHs}$. Once its solubility does not depend on the $\mathrm{pH}$, there was no phase separation nor precipitation.

This behavior was not observed for the soy protein isolate, which presented high absorbance values at $\mathrm{pHs}$ between 4.0 and 5.0. These higher absorbance values resulted along the lowest solubility values, which suggests that the solution's turbidity is connected with the suspended particulate matter. On the other hand, for $\mathrm{pHs}$ lower than 4.0 and higher than 5.0, the absorbance reading values for this biopolymer were lower, resulting along higher solubility values and, consequently, lower quantity of precitpitated matter.

For the systems in which the biopolymers were present at different concentrations, as solutions became more alkaline, the absorbance reading values became lower, which suggests a lower attractive interaction between them and lower complex formation. This result confirms the one obtained from the biopolymers charges analysis, in which at $\mathrm{pH}$ higher than 4.5 the absorbance reading values were lower than 0.1 a.u. for all analyzed proportions.

For the same $\mathrm{pH}$, the increase in proportion of soy protein isolate was followed by an increase in the absorbance reading value, which leads to the conclusion that a higher complex formation occurred, mainly in more acid solutions.

It is noteworthy that the systems at $\mathrm{pH} 3.0$ generated absorbance reading values higher than the systems at $\mathrm{pH} 3.5$. Even though they suggested a higher complex formation at $\mathrm{pH} 3.0$, the systems were less stable than at $\mathrm{pH} 3.5$, with a

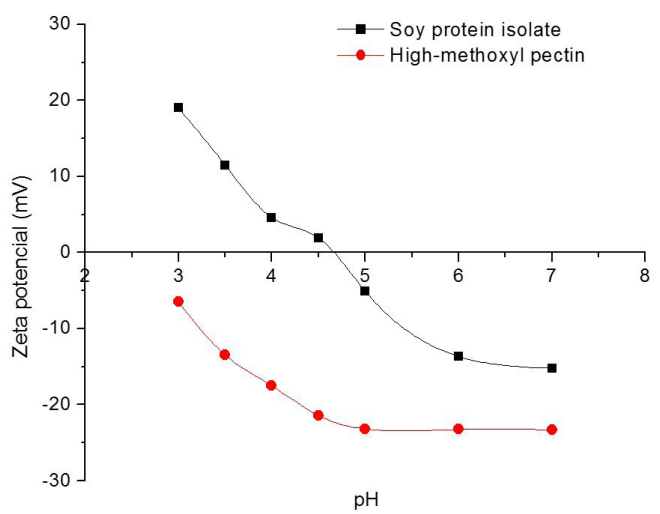

Figure 2. Influence of $\mathrm{pH}$ on zeta potential $(\mathrm{mV})$ of solutions of soy protein isolate and high-methoxyl pectin.

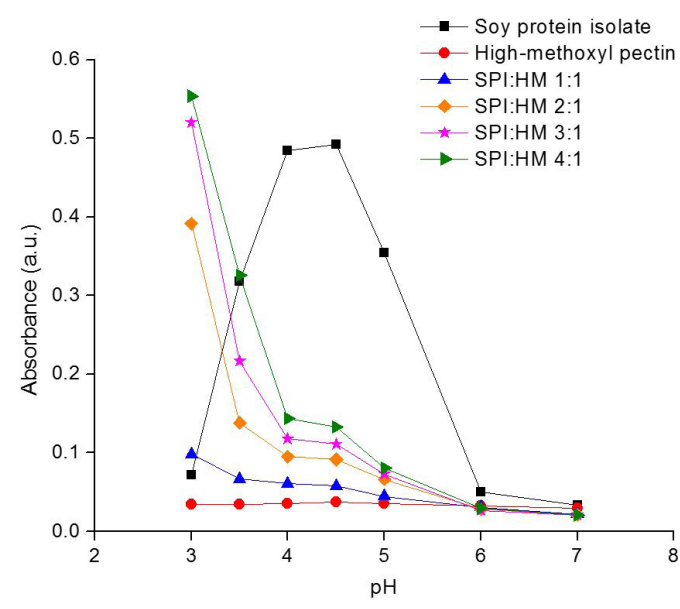

Figure 3. Influence of $\mathrm{pH}$ on absorbance reading, at wavelength $590 \mathrm{~nm}$, for individual biopolymer solutions and the pair at different proportions. 


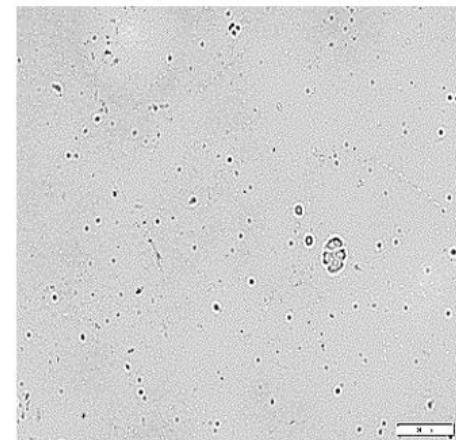

(a)

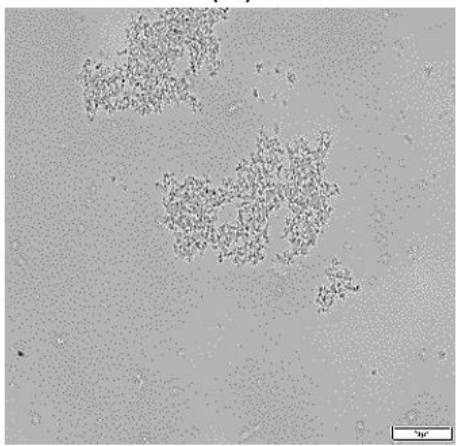

(c)

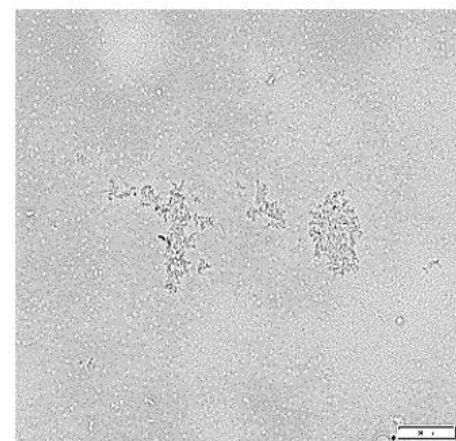

(b)

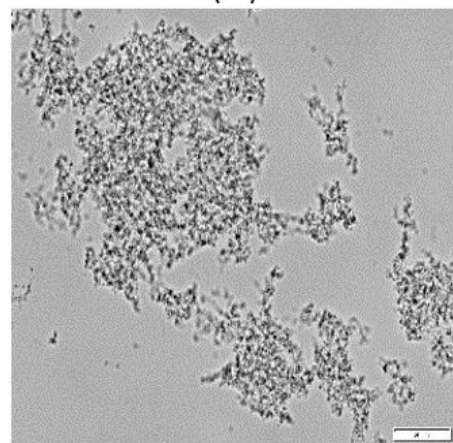

(d)

Figure 4. Images of systems at pH 3.0 with SPI:HM proportions of 1:1 (a), 2:1 (b), 3:1 (c), and 4:1 (d), obtained through optical microscopy with 40x magnifying lenses.

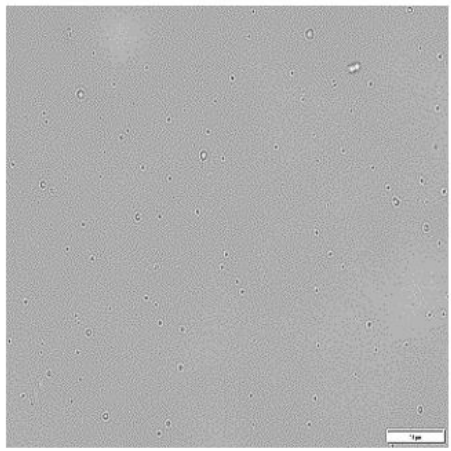

(a)

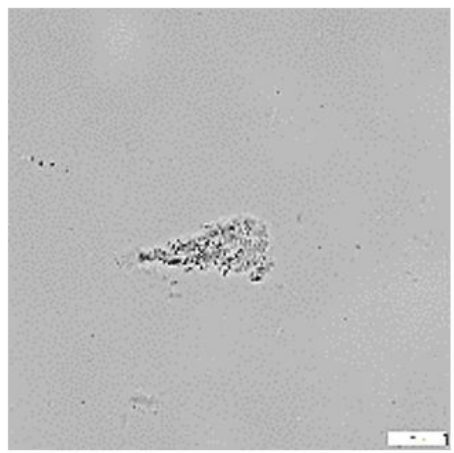

(c)

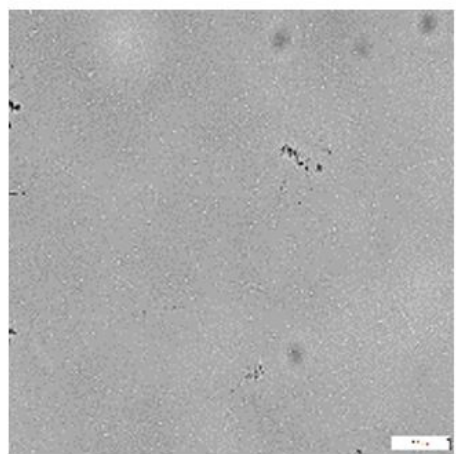

(b)

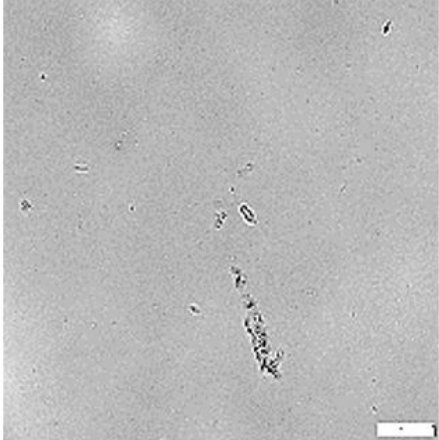

(d)

Figure 5. Images of systems at pH 3.5 with SPI:HM proportions of 1:1 (a), 2:1 (b), 3:1 (c), and 4:1 (d), obtained through optical microscopy with 40x magnifying lenses. 
precipitation and phase separation in few minutes, which is undesirable in food systems such as emulsions.

Based on these remarks, solutions at $\mathrm{pH} 3.5$ were considered ideal for an attractive interaction and complex formation between the studied biopolymers to happen, being suitable to elaborate stable food systems, such as acidic beverages based on protein or emulsions.

Jasentuliyana et al. ${ }^{[20]}$ studied the interaction between the soy protein isolate and citric pectin with the objective of enhancing the use of the soy protein isolate as a turbidity agent in acidic beverages ( $\mathrm{pH} 3.7)$. The authors then separated the soy protein isolate in two fractions, a hydrophobic and a hydrophilic one and evaluated the interaction between these and pectin through turbidity studies. They did not observe significant differences between the two fractions and reported that the higher the protein proportion, the higher the solution's absorbance reading value, confirming the use of the soy protein isolate as an opacity agent. Besides, the systems elaborated at protein:pectin proportion of $2: 1$ and 1:4 showed the highest stability values throughout 28 days.

Another study on the pair formed by the soy protein isolate and high-methoxyl pectin was conducted by Albano and Telis ${ }^{[21]}$, at $\mathrm{pH} 3.5$. The authors confirmed the effect of stability by pectin in protein solutions close to the protein's isoelectric point. Besides, they observed the formation of small complexes which, when submitted to rheological tests, showed a slightly pseudoplastic behavior, with a tendency to a Newtonian behavior. When the biopolymer solutions were submitted to ultrasound, it was observed that the complexes had their sizes reduced and suffered a consequent reduction of the phases separation after $24 \mathrm{~h}$.

In a study on the interaction between soy protein and gum Arabic conducted by Dong et al. ${ }^{[7]}$ it was found that, at $\mathrm{pH} 3.0$, the addition of gum arabic in a soy protein solution increased the system's absorbance value. Moreover, the systems with a protein:polysaccharide proportion of 1.5:1 and $3: 1$ were instable.

\subsection{Morphology}

Through images obtained from optical microscopy, it was possible to observe the morphology of both the biopolymer solutions individually and the systems at different proportions for the studied $\mathrm{pHs}$, confirming the results obtained through solubility, charges, and turbidimetry tests.

For the soy protein isolate solution, the formation of aggregates was observed at pHs between 4.0 and 5.0, at which lower solubility and higher absorbance values were noted. For the remaining $\mathrm{pHs}$, there was no presence of complexes.

The pectin solution was solubilized at all different $\mathrm{pHs}$, and aggregates were not noted.

For systems containing different biopolymers proportions, there was a higher formation of complexes at $\mathrm{pHs} 3.0$ and 3.5, and those increased as the soy protein isolate concentration increased in the solution. These results are observed for $\mathrm{pH}$ 3.0 in Figure 4 and for pH 3.5 in Figure 5.

Although the complexes were smaller in $\mathrm{pH} 3.5$, as expected by the results of turbidimetry, they were more soluble and more stable being suitable to elaborate food systems.
The systems in higher $\mathrm{pH}$ solutions did not present formation of complex, thus confirming a lower attractive interaction between the biopolymers.

\section{Conclusions}

Through tests for characterization of the biopolymers, it was observed that high-methoxyl pectin showed high solubility, disregarding $\mathrm{pH}$, and that negative charges increased as $\mathrm{pH}$ increased until they reached a plateau. The soy protein isolate showed low solubility at its isoelectric point which increased in alkaline solutions, until it reached $100 \%$ at $\mathrm{pH}$ 11.0. Besides, positive charges below the isoelectric point and negative ones above this point were found.

In solutions with a $\mathrm{pH}$ lower than the isoelectric point, an attractive interaction between the soy protein isolate and high-methoxyl pectin was verified by analyzing the formation of complexes. These complexes were bigger for the systems with a higher protein proportion.

The complexes formed in $\mathrm{pH} 3.5$, in the different ratios, have potential application in the food industry, for example, as emulsifiers, foam stabilizers, fat replacers or being used in encapsulation.

\section{Acknowledgements}

The authors acknowledge Sao Paulo Research Foundation, FAPESP (Processes 2014/08520-6, 2013/10842-9 and 2014/02910-7) and Coordination for the Improvement of Higher Level Personnel, CAPES.

\section{References}

1. Tömösközi, S., Lásztity, R., Haraszi, R., \& Baticz, O. (2001). Isolation and study of the functional properties of pea proteins. Die Nahrung, 45(6), 399-401. PMid:11712241. http:// dx.doi.org/10.1002/1521-3803(20011001)45:6<399::AIDFOOD399>3.0.CO;2-0.

2. Lam, M., Paulsen, P., \& Corredig, M. (2008). Interactions of soy protein fractions with high-methoxyl pectin. Journal of Agricultural and Food Chemistry, 56(12), 4726-4735. PMid:18517218. http://dx.doi.org/10.1021/jf073375d.

3. Canteri, M. H. H., Moreno, L., Wosiacki, G., \& Scherr, A. P. (2012). Pectina: da matéria-prima ao produto final. Polímeros: Ciência e Tecnologia, 22(2), 149-157. http://dx.doi.org/10.1590/ S0104-14282012005000024.

4. Santos, M. S., Petkowicz, C. L. O., Haminiuk, C. W. I., \& Cândido, L. M. B. (2010). Polissacarídeos extraídos da gabiroba (Campomanesia xanthocarpa Berg): propriedades químicas e perfil reológico. Polímeros: Ciência e Tecnologia, 20, 352-358. http://dx.doi.org/10.1590/S0104-14282010005000056.

5. Tromp, R. H., de Kruif, C. G., van Eijk, M., \& Rolin, C. (2004). On the mechanism of stabilization of acidified milk drinks by pectin. Food Hydrocolloids, 18(1), 565-572. http:// dx.doi.org/10.1016/j.foodhyd.2003.09.005.

6. Lam, M., Shen, R., Paulsen, P., \& Corredig, M. (2007). Pectin stabilization of soy protein isolates at low pH. Food Research International, 40(1), 101-110. http://dx.doi.org/10.1016/j. foodres.2006.08.004.

7. Dong, D., Li, X., Hua, Y., Chen, Y., Kong, X., Zhang, C., \& Wang, Q. (2015). Mutual titration of soy proteins and gum arabic and the complexing behavior studied by isothermal titration calorimetry, turbidity and ternary phase boundaries. 
Food Hydrocolloids, 46(1), 28-36. http://dx.doi.org/10.1016/j. foodhyd.2014.11.019.

8. Jaramillo, D. P., Roberts, R. F., \& Coupland, J. N. (2011). Effect of $\mathrm{pH}$ on the properties of soy protein-pectin complexes. Food Research International, 44(1), 911-916. http://dx.doi. org/10.1016/j.foodres.2011.01.057.

9. Serfert, Y., Schroder, J., Mescher, A., Laackmann, J., Ratzke, K., Shaikh, M. Q., Gaukel, V., Moritz, H. U., Schuchmann, H. P., Walzel, P., Drusch, S., \& Schwarz, K. (2013). Spray drying behavior and functionality of emulsions with $\beta$-lactoglobulin/ pectin interfacial complexes. Food Hydrocolloids, 31(1), 438 445. http://dx.doi.org/10.1016/j.foodhyd.2012.11.037.

10. Mattison, K. W., Brittain, I. J., \& Dubin, P. L. (1995). Proteinpolyelectrolyte phase boundaries. Biotechnology Progress, 11(1), 632-637. http://dx.doi.org/10.1021/bp00036a005.

11. Mattison, K. W., Wang, Y., Grymonpré, K., \& Dubin, P. L. (1999). Micro and macro-phase behaviour in protein-polyelectrolytes systems. Macromolecular Symposia, 140(1), 53-76. http:// dx.doi.org/10.1002/masy.19991400107.

12. Marfil, P. H. M. (2014). Microencapsulação de óleo de palma por coacervação complexa em matrizes de gelatina/goma arábica e gelatina/alginato (Doctoral thesis). Universidade Estadual Paulista “Julio de Mesquita Filho", São José do Rio Preto.

13. Cano-Chauca, M., Stringheta, P. C., Ramos, A. M., \& CalVidal, J. (2005). Effect of the carriers on the microstructure of mango powder obtained by spray drying and its functional characterization. Innovative Food Science \& Emerging Technologies, 6(1), 420-428. http://dx.doi.org/10.1016/j. ifset.2005.05.003.

14. Perrechil, F. A., \& Cunha, R. L. (2013). Stabilization of multilayered emulsions by sodium caseinate and $\kappa$-carrageenan. Food Hydrocolloids, 30(1), 606-613. http://dx.doi.org/10.1016/j. foodhyd.2012.08.006.

15. Antonov, Y.A., \& Zubova, O. M. (2001). Phase state of aqueous gelatin-polysaccharide (1)-polysaccharide (2) systems. International Journal of Biological Macromolecules, 29(2),
67-71. PMid:11518577. http://dx.doi.org/10.1016/S01418130(01)00140-4.

16. Renkema, J. M. S., Gruppen, H., \& Van Vliet, T. (2002). Influence of $\mathrm{pH}$ and ionic strength on heat-induced formation and rheological properties of soy protein gels in relation to denaturation and their protein compositions. Journal of Agricultural and Food Chemistry, 50(21), 6064-6071. PMid:12358481. http://dx.doi.org/10.1021/jf020061b.

17. Malhotra,A., \& Coupland, J. N. (2004). The effect of surfactants on the solubility, zeta potential, and viscosity of soy protein isolates. Food Hydrocolloids, 18(1), 101-108. http://dx.doi. org/10.1016/S0268-005X(03)00047-X.

18. Rocha, G. O., Farias, M. G., Carvalho, C. W. P., Ascheri, J. L. R., \& Galdeano, M. C. (2014). Filmes compostos biodegradáveis a base de amido de mandioca e proteína de soja. Polímeros: Ciência e Tecnologia, 24(5), 587-595. http:// dx.doi.org/10.1590/0104-1428.1355.

19. Harnsilawat, T., Pongsawatmanit, R., \& McClements, D. J. (2006). Characterization of $\beta$-lactoglobulin-sodium alginate interactions in aqueous solutions: A calorimetry, light scattering, electrophoretic mobility and solubility study. Food Hydrocolloids, 20(1), 577-585. http://dx.doi.org/10.1016/j. foodhyd.2005.05.005.

20. Jasentuliyana, N., Toma, R. B., Klavons, J. A., \& Medora, N. (1998). Beverage cloud stability with isolated soy protein. Journal of the Science of Food and Agriculture, 78(1), 389-394. http:// dx.doi.org/10.1002/(SICI)1097-0010(199811)78:3<389::AIDJSFA130>3.0.CO;2-Z.

21. Albano, K. M., \& Telis, V. R. N. (2015). Rheological investigation of ultrasound effect on interactions between soy protein isolate and pectin. In Proceedings of the VII Brazilian Conference on Rheology (pp. 22-25). Curitiba: Universidade Tecnológica Federal do Paraná. 